\title{
ASSESSMENT OF THE FINANCIAL TECHNOLOGIES INFLUENCE ON COUNTY'S COMPETITIVENESS
}

\author{
Irena Danileviciene $^{1}$, Mantas Sakalauskas ${ }^{2}$ and Laima Okuneviciute Neverauskiene ${ }^{3}$ \\ 1,2 Vilnius Gediminas Technical University, Faculty of Business Management, Sauletekio al. \\ 11, 10223 Vilnius, Lithuania \\ ${ }^{3}$ Vilnius Gediminas Technical University, Faculty of Business Management, Lithuanian Social \\ Research Centre, Sauletekio al. 11, 10223 Vilnius, Lithuania
}

DOI: 10.46609/IJSSER.2021.v06i01.015 URL: https://doi.org/10.46609/IJSSER.2021.v06i01.015

\begin{abstract}
While the FinTech sector is expanding rapidly and making up a larger share of the whole finance sector, and Lithuania taking measures in order to attract more FinTech companies, the need to determine the dependency between FinTech and a country's competitiveness arises. The purpose of this article is to evaluate FinTech influence on a country's competitiveness. Theoretical part of the article defined FinTech and competitiveness as terms. FinTech ecosystem and classification of firms were also analysed. Six macroeconomical indicators that could possibly influence a country's competitiveness were distinguished. Furthermore using the correlation-regression analysis method, FinTech influence on the six macroeconomical indicators, that are expressed quantitatively and define a country's competitiveness, was determined. According to the results of the research, FinTech influences four of the six selected macroeconomical indicators, these indicators are - GDP, average annual wage, unemploymentand exports.
\end{abstract}

Keywords: FinTech, financial technologies, competitiveness, GDP, unemployment,exports, productivity, income inequality, wage

\section{Introduction}

Research relevance: According to the Ministry of Finance of the Republic of Lithuania (2017), the term „FinTech“ is used to describe new decisions that reflect the growing development of processes, commodities or business models related to innovation in the financial service sector. The main objective of this sector is making financial services faster, cheaper, safer and more effective. Growth of this segment of the financial sector in Lithuania is highlighted in Invest in Lithuania (2019) agencies report. Based on this report FinTech sector having doubled in the past 
International Journal of Social Science and Economic Research

ISSN: 2455-8834

Volume:06, Issue:01 "January 2021"

two years is experiencing dramatic growth. The number of FinTech companies in Lithuania during 2014-2019 has more than tripled and the number of employees in 2018 compared to 2017 in the FinTech sector has increased by 37 percent. Keeping in mind the fact that Lithuania is taking measures in order to attract more FinTech companies, the necessity to determine FinTech influence on a country's competitiveness arises. Therefore influence of theFinTech sector to the country's competitiveness is a relevant subject.

Research problem. Does FinTech influence a country`s competitiveness?

Research object - Financial Technologies (FinTech).

Research novelty - while analysing scientific literature, no articles matching or similar to the subject were found, thus the subject is new and relevant, especially keeping in mind, that the FinTech sector experienced dramatic growth only recently and that there is no unanimous database, where statistical FinTech data from various countries could be found.

Research objective - assess FinTech influence on a country‘s competitiveness.

\section{Research tasks:}

1. Analyse theoretical aspects of FinTech.

2. Define competitiveness and factors influencing it.

3. Determine whether FinTech influences a country`s competitiveness.

4. Assess FinTech influence to a country's competitiveness indicators.

Research methods - analysis of scientific literature, correlation-regression analysis, systematization and comparison of statistical data.

\section{Theoretical aspects pertaining FinTech}

\subsection{FinTech}

FinTech covers digital innovations and technology-enabled business model innovations in the financial sector (Philippon, 2016). Such innovations can disrupt existing industry structures and blur industry boundaries, facilitate strategic disintermediation, revolutionize how existing firms create and deliver products and services, provide new gateways for entrepreneurship, democratize access to financial services, but also create significant privacy, regulatory and law enforcement challenges. Examples of innovations that are central to FinTech today includecrypto 


\section{International Journal of Social Science and Economic Research}

ISSN: $2455-8834$

Volume:06, Issue:01 "January 2021"

currencies and the blockchain, new digital advisory and trading systems, artificial intelligence and machine learning, peer-to-peer lending, equity crowd funding and mobile payment systems (Philippon, 2016).

Nicoletti (2017) From around 1866 to 1967, the financial services industry, while heavily interlinked with technology, remained largely an analog industry, at least in its public image. This is the period of fintech 1.0.

From 1967, the development of digital technology for communications and processing of transactions increasingly transformed finance from an analog to a digital industry. By 1987 at the latest, financial services, at least in developed countries, had become not only highly globalized, but also digitized. This period of fintech 2.0 continued until 2008. (Nicoletti, 2017). Since 2008, a new stage has started (fintech 3.0). New startups and established technology companies have begun to deliver financial products and services directly to businesses and consumers (Nicoletti, 2017).

Nowadays, industry 4.0 is a vision of an increased connection between physical and virtual industrial machines (Schlechtendahl, Keinert, Kretschmer \& Lechler, 2014). This computerization of manufacturing brings many benefits, allowing data gathering, integration, and analysis on a scale not seen earlier (Nicoletti, 2017). Table 1 lists FinTech definitions according to different authors.

Table 1. FinTech definitions according to different authors (compiled by authors)

\begin{tabular}{|l|l|}
\hline \multicolumn{1}{|c|}{ Author, year } & \multicolumn{1}{c|}{ FinTech interpretation } \\
\hline $\begin{array}{l}\text { Ministry of Finance of } \\
\text { the Republic of } \\
\text { Lithuania (2017) }\end{array}$ & $\begin{array}{l}\text { FinTech - new decisions that reflect the growing } \\
\text { development of processes, commodities or } \\
\text { business models related to innovation in the } \\
\text { financial service sector. }\end{array}$ \\
\hline Sanicola (2017) & $\begin{array}{l}\text { FinTech companies are businesses that facilitate } \\
\text { new technology, which would create new and } \\
\text { better financial services to both consumers and } \\
\text { businesses. This involves various companies, } \\
\text { which can operate within finance management, } \\
\text { insurance, payment, wealth management or other } \\
\text { areas. }\end{array}$ \\
\hline
\end{tabular}


International Journal of Social Science and Economic Research

ISSN: 2455-8834

Volume:06, Issue:01 "January 2021"

\begin{tabular}{|l|l|}
\hline Kagan (2019) & $\begin{array}{l}\text { Financial technology (FinTech) is used to } \\
\text { describe a new technology that aims to better and } \\
\text { automate the use of financial services. }\end{array}$ \\
\hline Oxford dictionary (2019) & $\begin{array}{l}\text { Computer programs or other technologies used } \\
\text { to sustain and facilitate bank and financial } \\
\text { operations. }\end{array}$ \\
\hline
\end{tabular}

Based on interpretations of different authors FinTech is a financial sector, that facilitates innovation in the finance sector nad aims to better and automate financial services.

\section{FinTech ecosystem and company classification}

One American research company group „CB Insights“, which works with investors and investor databases has created a FinTech periodic table. According to Ryabova (2015) FinTech periodic tables differentiates seven types of ogranisations based areas of operation:

1. Lending. Private landing companies, P2P-lending, lending platforms using machines learning technologies and algorithms to assess creditworthiness.

2. Payments or Billing Tech. Payments processing, bill preparing.

3. Personal Finance or Asset Management that help in managing personals bills, accounts, credits, investments.

4. Money Transfer or Remittance. P2P-platforms to transfer money between clients across countries.

5. Digital currency. Software in the digital currency sphere.

6. Institutional tools providing tools to banks, hedge funds, mutual funds or other institutional investors.

7. Equity crowdfunding - platforms for providing monetary contribution for projects or companies.

Lee \& Shin (2018) have identified five main elements of the FinTech ecosystem (Figure 1): 
1. Fintech startups (e.g., payment, wealth management, lending, crowd funding, capital market, and insurance fintech companies).

2. Technology developers (e.g., big data analytics, cloud computing, crypto currency,and social media developers).

3. Government (e.g., financial regulators and legislature).

4. Financial customers (e.g., individuals and organisations); and

5. Traditional financial institutions (e.g., traditional banks, insurance companies, stock brokerage firms, and venture capitalists).

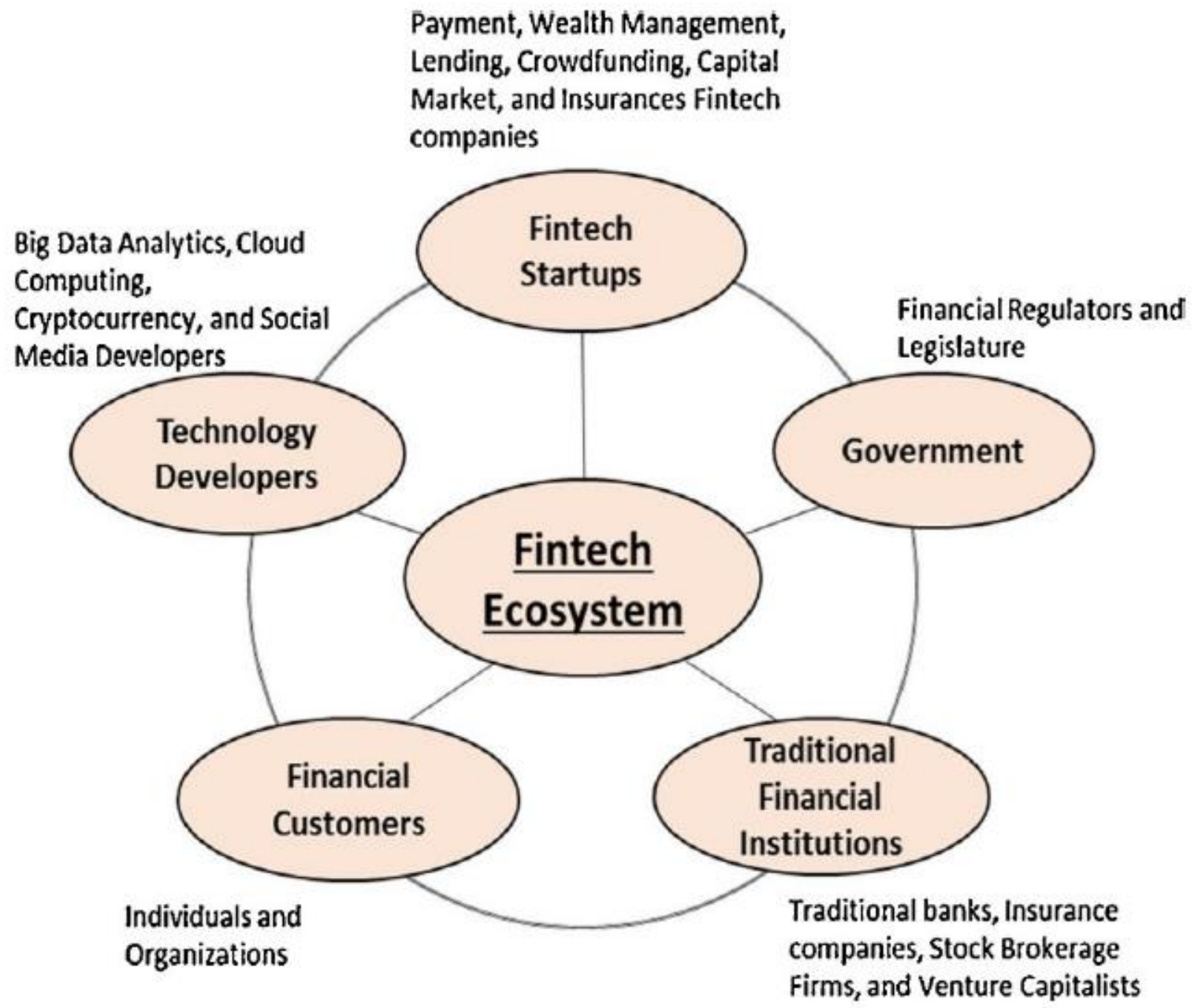

Figure 1. Five elements of the FinTech ecosystem (Lee \& Shin, 2018)

These elements symbiotically contribute to the innovation, stimulate economy, facilitate collaboration and competition in the financial industry, and ultimately benefit consumers in the financial industry. 


\section{International Journal of Social Science and Economic Research}

ISSN: $2455-8834$

Volume:06, Issue:01 "January 2021"

In today's financial services sector, FinTech start-ups offer consumer-oriented banking, insurance, and other financial services. They are the key innovation driver with experts predicting a very promising future. Offering innovative financial services as asset-light and compliance-easy organizations, FinTech start-ups evolve into challenging competitors and strong allies of traditional financial institutions. By 2020, FinTechstart-ups are estimated to handle over $20 \%$ of the financial service business (Gimpel, Rau \& Roglinger, 2017). Financialcustomers are the source of revenue generation for fintech companies. While large organizations are important sources of revenue, the predominant revenue source for fintech companies are individual customers and small and medium-sized enterprises (SMEs) (Lee \& Shin, 2018).

Traditional financial institutions are also a major driving force in the fintech ecosystem. After realizing the disruptive power of fintech and dwindling window of opportunities to blunt fintech's impact on the market, traditional financial institutions have been reevaluating their existing business models and developing strategies to embrace fintech innovation (Lee \& Shin, 2018). Technology developers provide digital platforms for social media, big data analytics, cloud computing, artificial intelligence, smart phones, and mobile services. Technology developers create a favorable environment for fintech startups to launch innovative services rapidly (Lee \& Shin, 2018)

Development of the financial technology sector is envisaged in the government program approved by the parliament of the Republic of Lithuania and also in the operational strategy ofthe Bank of Lithuania. Lithuanian breakthrough in this area is positively received by residents more interested in innovation as well as both Lithuanian and foreign media (including BBC, Forbes, Bloomberg), that introduces Lithuania as a country open to advancement and innovation (Ministry of Finance of the Republic of Lithuania, 2019).

\section{Theoretical aspects pertaining a country's competitiveness}

A country's competitiveness and the place of exports have long been important public consideration subjects in various countries around the world. There topic is important not onlyto academics and experts, but also politicians who are always amidst of making decisions regarding a country's unilateral and multilateral regulation of economic relations, which oftendo not match recommendations of analysts (Vilpišauskas, 2004).

Competitiveness expresses relative, that is relative company, economy branch, region, countryor a group of countries (economical, social, technological, etc.) position based on other companies, economy branches, countries and groups of countries (Navickas, Malakauskaite, 2010). Thus in order to assess FinTech influence on a country's competitiveness the assessment will be conducted on a macro scale. Table 2 lists different competitiveness interpretations basedon different authors. 
International Journal of Social Science and Economic Research

ISSN: 2455-8834

Volume:06, Issue:01 "January 2021"

Table 2. Competitiveness interpretation according to different authors (compiled by authors)

\begin{tabular}{|c|l|}
\hline Author, year & \multicolumn{1}{c|}{ Interpretation } \\
\hline $\begin{array}{c}\text { Aiginger, Barenthaler-Sieber \& } \\
\text { Vogel (2013) }\end{array}$ & $\begin{array}{l}\text { Ability of a country (region, location) to deliver the } \\
\text { beyond GDP goals for its citizens. }\end{array}$ \\
\hline World Economic Forum (2016) & $\begin{array}{l}\text { The set of institutions, policies and factors that } \\
\text { determine the level of productivity of a country }\end{array}$ \\
\hline Business Dictionary (2019) & $\begin{array}{l}\text { Ability of a firm or a nation to offer products and } \\
\text { services that meet the quality standards of the local and } \\
\text { world markets at prices that are competitive and provide } \\
\text { adequate returns on the resources employed or } \\
\text { consumed in producing them. }\end{array}$ \\
\hline Cambridge Dictionary (2019) & $\begin{array}{l}\text { The fact of being able to compete successfully with } \\
\text { other companies, countries, organizations etc. }\end{array}$ \\
\hline
\end{tabular}

Based on listed interpretations it can be seen that competitiveness is described very differently according to different authors.

Competitiveness has been widely analysed in scientific literature. Vilpišauskas (2004) analysed international competitiveness and Lithuanian export policies. One of the article conclusions lists export policy, author claims that export policy and it's measures have to be linked to country's (companies) competitiveness condition improvement. Based on this, a conclusion can be made, that export may influence a country's competitiveness.

Bruneckienè (2010) analysed and assessed country's regional competitiveness using different methods. Research showed that a country's regional competitiveness cannot be fully reflected by a single economical and/or social micro or macro scale indicator as well as indicator comparison between similar indicators of other regions, therefore a complex competitiveness assessment is necessary (Bruneckienè, 2010).

Staskevičiūtė \& Tamošiūnienè (2010) analysed a country's competitiveness: evolution of the concept over time. Main aspects pertaining a country's competitiveness were identified based on different authors. These aspects were broken down by authors into social welfare, employment, productivity, trade, appeal, objectives, politics, flexibility and growth. 


\section{International Journal of Social Science and Economic Research}

ISSN: $2455-8834$

Volume:06, Issue:01 "January 2021"

Rakauskienè \& Tamošiūnienė (2013) researched indicators influencing a country's competitiveness. The paper listed the world competitiveness index structure based on indicator areas. Identified as macroeconomic environment indicators were - health and primary education, higher education and studies, product market effectiveness, financial market growth, market size, etc.

Aiginger, Barenthaler-Sieber \& Vogel (2013) define six main (traditional) marcoeconomic indicators that influence a country's competitiveness. These indicators are: employment, unemployment, GDP per capita, budget deficit, country debt, current account. Social indicators were described as wage, poverty level, income inequality.

Matuzevičiūtè, Vaitiekūnaitè \& Butkus (2015) assessed European Union countries competitiveness and it's determinants. The paper identified these determinants as labor market, marcoeconomical situation, scientific infrastructure and technological improvement, product and service market as well as education. Most of these determinants were expressed as GDP or a ratio of this indicator. Results of the analysis showed that despite countries economic and social development level, competitiveness is mostly influenced by the ratio of employed and unemployed persons and export, GDP per capita. The least influential indicators for a country ${ }^{6} \mathrm{~s}$ competitiveness were noted as productivity and unemployment indicators, work force share with a higher education. It was also determined that even household expense and per capita expenditure on research and development variations are significant to very competitive countries. Increase of per capita expenditure on research and development, have a significant positive impact on a country's competitiveness, GDP per capita and productivity per hour indicator increase is influenced by increasing export per capita (Matuzevičiūtè, Vaitiekūnaite \& Butkus 2015).

Authors Djogo \& Stanisic (2016) were researching whether the World Competitiveness report is a valid macroeconomical competitiveness gauge. According to authors, a few main macroeconomical indicators, that are expressed quantitatively and possibly influence a country's competitiveness are:

- GDP (GDP, GDP per capita, GDP annual growth)

- Wage

- Income inequality

- Export

- Employment and unemployment

- Productivity.

\section{Assessment methodology}


International Journal of Social Science and Economic Research

ISSN: 2455-8834

Volume:06, Issue:01 "January 2021"

Assessment will be conducted to determine FinTech influence on Lithuania's competitiveness, therefore this assessment will utilize Invest in Lithuania agency“s „The FinTech Landscape in Lithuania" report, that lists FinTech company number in Lithuania in the timeframe of 20142019. Maroeconomical indicator data that includes GDP, average annual wages, income inequality, unemployment, productivity will be sourced from Eurostat, OECD, World Bank databases. Correlation-regression analysis method to conduct the assessment of FinTech influence on a country's competitiveness will be used.

\section{Correlation}

Correlation coefficient is a measure of linear association between two variables. This correlation coefficient is between the value of -1 and +1 . Usually in scientific research $Y$ is considered as a dependant variable and $\mathrm{X}$ is considered as an independent variable.

Often when analysing the variance of values of quantitative variables $\mathrm{X}$ and $\mathrm{Y}$, a question needs to be answered, are observed variables dependent or independent? What is the relationship tendency between $\mathrm{X}$ and $\mathrm{Y}$ ? For example, while $\mathrm{X}$ increases, an increase or decrease tendencyof $\mathrm{Y}$ variable can be observed. This tendency can be monotonous (when all $\mathrm{X}$ value connections between $\mathrm{X}$ and $\mathrm{Y}$ is the same, for example when $\mathrm{X}$ values increase, $\mathrm{Y}$ values also always increase) or non monotonous. What is the type of this statistical connection? It can be linear or non-linear (square, logarithmic, exponential, etc.). Statistical connection tendency and type is often assessed with X and Y variable scatter diagram (Janilionis, 2011). Correlationcoefficient is calculated based on this formula (Corporate Finance Institute, 2019).

$$
r_{x y}=\frac{\sum\left(x_{i}-\bar{x}\right)\left(y_{i}-\bar{y}\right)}{\sqrt{\sum\left(x_{i}-\bar{x}\right)^{2} \sum\left(y_{i}-\bar{y}\right)^{2}}}
$$

\section{In this formula:}

$\mathrm{r}_{\mathrm{xy}}$ - variable $\mathrm{x}$ and $\mathrm{y}$ linear relationship coefficient;

$\mathrm{x}_{\mathrm{i}}-\mathrm{x}$ variable values;

$\mathrm{y}_{\mathrm{i}}-\mathrm{y}$ variable values;

$\bar{x}-\mathrm{x}$ value mean;

$\bar{y}-\mathrm{y}$ value mean.

Table 3 describes what kind of assessment should be made based on the correlation coefficient between variables. 
International Journal of Social Science and Economic Research

ISSN: 2455-8834

Volume:06, Issue:01 "January 2021"

Table 3. Interpretations of correlation coefficient (Mukaka, 2012)

\begin{tabular}{|l|l|}
\hline Correlation value & Interpretation \\
\hline 0.90 to $1.00(-0.90$ to -1.00$)$ & Very strong positive (negative) correlation \\
\hline 0.70 to $0.90(-0.70$ to -0.90$)$ & Strong positive (negative) correlation \\
\hline 0.50 to $0.70(-0.50$ to -0.70$)$ & Medium positive (negative) correlation \\
\hline 0.30 to $0.50(-0.30$ to -0.50$)$ & Weak positive (negative) correlation \\
\hline 0.00 to $0.30(0.00$ to -0.30$)$ & Negligible correlation \\
\hline
\end{tabular}

As seen in table 3, correlation coefficient intervals and appropriate interpretations are listed. According to Mukaka (2012) when the correlation coefficient is between 0,9 and 1 (-0,9 and -1) - a very strong positive (negative) correlation connection is observed, from 0,7 to 0,9 ( $-0,7$ to $0,9)$ - strong positive (negative) correlation, from 0,5 to $0,7(-0,5$ to $-0,7)$ - medium positive (negative) correlation, from 0,3 to $0,5(-0,3$ to $-0,5)$ - weak positive (negative) correlation, from 0 to $0,3(0$ to $-0,3)-$ negligible correlation.

\section{Linear regression model}

Linear regression equation shows how change in independent variable, in this case variables, changes the dependent variable. This equation will be important for this assessment because it will show what kind of influence dependent variable facilitates towards the independent variables, for example when an independent variable increases, the dependent variable also increases, this would be described as a positive influence.

Linear regression model is comprised of a dependent variable $\mathrm{Y}$ and an independent variable $\mathrm{X}$ or other independent variables. The second (Janilionis, 2011) describes the linear dependency between $\mathrm{X}$ and $\mathrm{Y}$ variables.

$$
Y=\beta_{0}+\beta_{1} X
$$

In the second formula $\beta_{0}$ module is intercept, which is crossed by a line in $Y$ axis, coefficient $\beta_{1}$ is called slope and is equal the tangent of the angle formed by the regression line with the $\mathrm{X}$ axis

(Janilionis, 2011). Calculation B 0 and B1 is listed in formulas 3 and 4 (Janilionis, 2011): 


$$
\begin{array}{r}
\beta_{0}=\bar{y}-\beta_{1} \bar{x} \\
\beta_{1}=\frac{\overline{x y}-\bar{x} * \bar{y}}{\overline{x^{2}}-\bar{x}^{2}}
\end{array}
$$

In formulas 3 and 4 the stroke over $\mathrm{x}$ and $\mathrm{y}$ marks the average of variable values.

\section{Regression function hypothesis verification}

In solving regression analysis problems, the question of interest is often whether the independent variable $\mathrm{X}$ influences the change in $\mathrm{Y}$. Usually $\mathrm{X}$ influence to $\mathrm{Y}$ is verified with anull hypothesis $\mathrm{H} 0: \beta 1=0$, coefficient next to $\mathrm{X}$ population is equal to zero. Alternative hypothesis $\mathrm{Ha}: \beta 1 \neq 0$ means the existence of linear dependency between $X$ and $Y$ variables (Janilionis, 2011). If an observed significance value $\mathrm{p}$ ir lower than the chosen confidence level $\alpha$, then null hypothesis is discarded (Janilionis, 2011). Scientific research often uses $\alpha=0,05$ confidence level thus the final $p$ value should be equal to 0,05 or lower, for the purpose of rejecting null hypothesis and for the variable to be considered significant, in cases of $p>0,05$ variable is considered insignificant. To summarize in this specific case regression calculations will be made for each macroeconomical indicator, if $\mathrm{p}$ value is higher than 0,05 , then FinTechand that specific variable will be considered independent from each other. Once regression calculation with all chosen macroeconomical indicators is complete, FinTech influence on a country's competitiveness will be determined, this influence can be either positive or negative.

\section{FinTech influence on a country's competitiveness assessment}

In order to assess FinTech influence on a country's competitiveness, this assessment used 20142019 timeframe statistical data, which were comprised of FinTech companies in Lithuania, GDP is expressed in millions of Eur., export is expressed as millions of Eur., average annual wage (AAW) is expressed in euros, productivity is expressed in a percentage, unemployment is expressed in a percentage and income inequality is expressed in a coefficient. Table 4 displays summarized correlation-regression analysis results. 
International Journal of Social Science and Economic Research

ISSN: 2455-8834

Volume:06, Issue:01 "January 2021"

Table 4. Correlation-regression analysis results (calculated and compiled by authors)

\begin{tabular}{|l|c|c|c|c|c|}
\hline Indicator & $\mathrm{R}$ & $\mathrm{R}^{2}$ & $\mathrm{P}$ & Regression equation & $\alpha$ \\
\hline GDP & 0.9967 & 0.9919 & 0.0000159 & $y=74.55 x+32743.37$ & 0.05 \\
\hline Export & 0.9524 & 0.9071 & 0.0033 & $y=64.94 x+25077.32$ & 0.05 \\
\hline$A A W$ & 0.9879 & 0.9759 & 0.000219 & $y=25.87 x+9208.97$ & 0.05 \\
\hline Productivity & 0.5602 & 0.3138 & 0.2476 & $\mathrm{y}=0.016 \mathrm{x}+0.27$ & 0.05 \\
\hline Unemployment & 0.8579 & 0.7360 & 0.0288 & $y=-0.015 x+7.08$ & 0.05 \\
\hline $\begin{array}{l}\text { Income } \\
\text { inequality }\end{array}$ & 0.1305 & 0.0170 & 0.8052 & $\mathrm{y}=-0.001 \mathrm{x}+7.05$ & 0.05 \\
\hline
\end{tabular}

Table 4 displays summarized results of the analysis. According to the results, in this case FinTech influences a country's competitiveness through GDP, export, AAW and unemployment. Other indicators are discarded due to a high $\mathrm{p}$ value, which is over 0,05 . This value indicated that productivity and income inequality are not influenced by FinTech in Lithuania.

GDP and FinTech correlation coefficient is the largest of all indicators and is close to a functional level. Determination coefficient indicates that 99,19 percent of the GDP value scatter can be explained by FinTech value scatter. $\mathrm{P}$ value is also the lowest this indicates, that the result is statistically significant and the variables dependent on each other. Regression question indicates that an increase in FinTech value facilitates increase in GDP value.

Export and FinTech correlation coefficient is also quite large at 0,9524 this indicates a very strong positive dependency. Determination value shows that 90,71 percent of export value scatter can be explained by FinTech scatter. P value is lower than 0,05 , this indicates, that the result is statistically significant and the variables dependent on each other. Regression questionindicates that an increase in FinTech value facilitates increase in export value.

AAW and FinTech correlation coefficient is higher than export at 0,9879 . This indicates a very strong positive dependency. Determination value shows that 97,59 percent of AAW value scatter can be explained by FinTech scatter. P value is lower than 0,05 , this indicates, that the result is statistically significant and the variables dependent on each other. Regression questionindicates that an increase in FinTech value facilitates increase in AAW value. 


\section{International Journal of Social Science and Economic Research}

ISSN: $2455-8834$

Volume:06, Issue:01 "January 2021"

Unemployment and FinTech correlation coefficient is a bit lower than other indicators at 0,8579, this indicates a strong positive dependency. Determination value shows that 73,60 percent of unemployment value scatter can be explained by FinTech scatter. P value is lower than 0,05 , this indicates, that the result is statistically significant and the variables dependent on each other. Regression question indicates that an increase in FinTech value facilitates decrease in unemployment value. In this case since the unemployment value is aimed at a decrease for a positive outcome, this result is positive.

\section{Conclusions}

1. While analysis FinTech it was noted that there is no universal definition to thetechnologies in author's literature, however to summarize authors, it can be claimed that FinTech are technologies, that facilitate innovation in the finance sector and seek tobetter and automise financial services. FinTech development is divided into four timeframes, the current timeframe is considered to be the third one. Also FinTech companies are divided into mainly seven areas, which include lending, payments, finance and capital management, digital currencies, institutional measures and crowd funding.

2. Based on different author's competitiveness research, main indicators that could possibly influence a country's competitiveness and are expressed quantitatively were distinguished. Indicators used in the assessment were - GDP, average annual wage, income inequality, export, unemployment and productivity. Correlation-regressionanalysis method was used to perform the research, assessment was performed based on calculated $\mathrm{p}$ values of each indicator.

3. After performing the assessment, it was noted that FinTech actually does influence a country's competitiveness, it was determined that:

a) FinTech influence on GDP is positive, increase in FinTech facilitates increase in GDP;

b) FinTech influence on export is positive, increase in FinTech facilitates increasein export;

c) FinTech influence on average annual wage is positive, increase in FinTechfacilitates increase in average annual wage;

d) FinTech influence on unemployment is positive, increase in FinTech facilitates decrease in unemployment.

According to research results, FinTech influence on a country's competitiveness can be assessed as positive since FinTech influences four of six macroeconomical indicators that a described in literature as competitiveness determinants. GDP is the most important as it is noted as the main determinants of competitiveness.

4. While assessing FinTech influence to Lithuania's competitiveness indicators, it was concluded that FinTech has the most influence to GDP and average annual wage 
International Journal of Social Science and Economic Research

ISSN: 2455-8834

Volume:06, Issue:01 "January 2021"

accordingly, based on their respective $\mathrm{p}$ values.

\section{References}

Aiginger, A., Barenthaler-Siber \& S., Vogel, J. (2013). Competitiveness under New

Perspectives.Retrieved from: https://www.oecd.org/eco/Competitiveness-under-New-

Perspectives.pdf

Bruneckienè, J. (2010). Salies regionų konkurencingumo vertinimas ịvairiais metodais: rezultatų analizè ir vertinimas. Ekonomika ir vadyba, 2010.15. Retrieved from:

https://etalpykla.lituanistikadb.lt/object/LT-LDB-

0001:J.04 2010 1367172729403/J.04 2010 1367172729403.pdf

Business Dictionary. (2019). Competitiveness. Retrieved from:

http://www.businessdictionary.com/definition/competitiveness.html

Cambridge Dictionary. (2019). Competitiveness. Retrieved from:

https://dictionary.cambridge.org/dictionary/english/competitiveness

CB Insights. (2014). The Periodic Table of FinTech.Retrieved from: https://www.cbinsights.com/research/fin-tech-periodic-table/

Djogo, M. \& Stanisic, N. (2016). Is the Global Competitiveness Report the right measure of macroeconomic competitiveness. Zbornik Radova Ekonomskog Fakulteta u Rijeci / Proceedings of Rijeka School of Economics, 34(1), 91-117. Retrieved from: DOI: 10.18045/zbefri.2016.1.91

Eurostat. (2019a). National accounts including GDP. Gross domestic product at market prices, GDP per capita. Retrieved from:

https://ec.europa.eu/eurostat/tgm/refreshTableAction.do?tab=table\&plugin=1\&pcode=tec00001 \&language $=\mathrm{en}$

Eurostat. (2019b). Goods and services, imports and exports. Retrieved from: https://ec.europa.eu/eurostat/web/products-datasets/product?code=tec00110

Eurostat. (2019c). Labour productivity per person employed and hour worked. Retrieved from:https://ec.europa.eu/eurostat/web/products-datasets/-/tesem160

Eurostat. (2019c). Unemployment by sex and age - annual average. Retrieved from: https://ec.europa.eu/eurostat/web/lfs/data/database?p_p_id=NavTreeportletprod_WAR_NavTree portletprod_INSTANCE_IFjhoVbmPFHt\&p_p_lifecycle=0\&p_p_state=normal\&p_p_mode=vie 
International Journal of Social Science and Economic Research

ISSN: 2455-8834

Volume:06, Issue:01 "January 2021"

$\underline{w} \& p \quad p \quad$ ol id=column-2\&p p col count $=1$

Eurostat. (2019d). Inequality of income distribution. Retrieved from:

https://ec.europa.eu/eurostat/web/products-datasets/product?code=tespm151

Gimpel, H., Rau, D., Roglinger, M. (2017). Understanding FinTech start-ups - a taxonomy of consumer-oriented service offerings. Electronic Markets, 28(3), 245-264. Retrieved from: https://doi.org/10.1007/s1252

Invest in Lithuania (2018). The FinTech Landscape in Lithuania. Retrieved from: https://investlithuania.com/wp-content/uploads/2019/01/The-FinTech-Landscape-in-LithuaniaReport-2018.pdf

Janilionis, V. (2011). Koreliacinès ir regresinès analizès pagrindai. Retrieved from: http://www.lidata.eu/files/mokymai/Janilionis_III/Koreliacines_ir_regresines_pagrindaiV.pdf

Kagan, J. (2019). Financial Technology - FinTech. Retrieved from: https://www.investopedia.com/terms/f/FinTech.asp

Lee, I., Shin, J.,Y. FinTech: Ecosystem, business models, investment decisions, and challenges. Business Horizons 61(1), 35-46. Retrieved from: https://doi.org/10.1016/j.bushor.2017.09.003

LR Finansų ministerija (2017). Eurofi - FinTech pramonės iššūkiai ir perspektyvos Europoje. Retrieved from: https://finmin.Irv.lt/lt/naujienos/eurofi-FinTech-pramones-issukiai-irperspektyvos-europoje

LR finansų ministerija. (2019). Devynios valstybès institucijos vienija jëgas rizikų valdyme FinTech srityje. Retrieved from: https://finmin.lrv.lt/lt/naujienos/devynios-valstybes-institucijosvienija-jegas- riziku-valdyme-FinTech-srityje

Matuzevičiūtè, K., Vaitekūnaitè, A., Butkus, M. (2015). Ekonomika ir vadyba: aktualijos ir perspektyvos, 2(37), 38-53. Europos Sajungos šalių konkurencingumo ir jị lemiančių veiksnių vertinimas. Retrieved from: https://etalpykla.lituanistikadb.lt/object/LT-LDB0001:J.04 2015 1535459021779/J.04 2015 1535459021779.pdf

Mukaka, M., M. (2012). A guide to appropriate use of Correlation coefficient in medical research. Malawi Medical Journal, 24(3), 69-71. Retrieved from: https://www.ajol.info/index.php/mmj/article/view/81576

Navickas, V., Malakauskaite, A. (2010). Konkurencingumo vertinimo metodologinès 
International Journal of Social Science and Economic Research

ISSN: 2455-8834

Volume:06, Issue:01 "January 2021"

problemos irribotumas. Verslas: teorija ir praktika, 11(1), 5-11. Retrieved from:

https://etalpykla.lituanistikadb.lt/object/LT-LDB

0001:J.04 2010 1367170286605/J.04 2010 1367170286605.pdf

Nicoletti, B. (2017). Future of FinTech. Palgrave Studies in Financial Services Technology, 17.

Retrieved from: DOI 10.1007/978-3-319-51415-4

OECD.(2019). Average annual wages. Retrieved from:

https://stats.oecd.org/Index.aspx?DataSetCode=AV_AN_WAGE

Oxford Dictionary. (2019). FinTech. Retrieved from:

https://www.lexico.com/en/definition/FinTech

Philippon, T. (2016). The FinTech Opportunity. NBER Working Paper No. 22476, 2. Retrieved from: https://www.nber.org/papers/w22476.pdf

Rakauskienė, G. \& Tamošiūnienė, R. (2013). Šalies konkurencingumą lemiantys veiksniai. Verslas:teorija ir praktika, 14(3), 177-187. Retrieved from:

https://www.researchgate.net/profile/Rima_Tamosiuniene/publication/269973892_Salies_konkur enci nguma_lemiantys_veiksniai/links/5729e2cb08ae057b0a076bba/Salies-konkurencingumalemiantys- veiksniai.pdf

Ryabova, A. (2015). Emerging FinTech market: types and features of new financial technologies. Journal of Economics and Social Sciences, 7. Retrieved from: http://earchive.tpu.ru/bitstream/11683/21714/1/jess-56-176.pdf

Sanicola, L. (2017). What is FinTech? Sanicola, L. (2017). What is FinTech? Huffington Post. Retrieved from: https://www.huffingtonpost.com/entry/what-is-fintech_ us_58a20d80e4b0cd37efcfebaa?guccounter=1

Schlechtendahl, J., Keinert, M., Kretschmer, F., Lechler, A. (2014). Making existing production systems Industry 4.0-ready. Prodcution Engineering 9(1): 1-6. Retrieved from: DOI:

10.1007/s11740- 014-0586-3

Staskevičiūtė, G. ir Tamošiūnienė, R. (2010). Šalies konkurencingumas: sampratos raida laiko perspektyvoje. Verslas: teorija ir praktika, 11(2), 159-167. Retrieved from:

https://etalpykla.lituanistikadb.lt/object/LT-LDB

0001:J.04 2010 1367171254788/J.04 2010 1367171254788.pdf

Vilpišauskas, R. (2004). Tarptautinis konkurencingumas ir Lietuvos eksporto politika. Retrieved 
International Journal of Social Science and Economic Research

ISSN: 2455-8834

Volume:06, Issue:01 "January 2021"

from: $\underline{\text { https://etalpykla.lituanistikadb.lt/object/LT-LDB- }}$

0001:J.04 2004 1367159540607/J.04 2004 1367159540607.pdf

World Economic Forum. (2016). What is competitiveness? Retrieved from:

https://www.weforum.org/agenda/2016/09/what-is-competitiveness/ 